\title{
RESEARCH
}

Open Access

\section{High lipoprotein(a) concentrations are associated with lower type 2 diabetes risk in the Chinese Han population: a large retrospective cohort study}

Qingan $\mathrm{Fu}^{1}$, Lijuan $\mathrm{Hu}^{2}$, Yuan $\mathrm{Xu}^{3}$, Yingping $\mathrm{Yi}^{3}$ and Long Jiang ${ }^{{ }^{*}}$ (D)

\begin{abstract}
Background: Lipoprotein (a) $[\mathrm{Lp}(\mathrm{a})]$ is a proven independent risk factor for coronary heart disease. It is also associated with type 2 diabetes mellitus (T2DM). However, the correlation between Lp(a) and T2DM has not been clearly elucidated.

Methods: This was a retrospective cohort study involving 9248 T2DM patients and 18,496 control individuals (1:2 matched). Patients were randomly selected from among inpatients in the Second Affiliated Hospital of Nanchang University between 2006 and 2017. Clinical characteristics were compared between the two groups. Spearman rank-order correlation coefficients were used to evaluate the strength and direction of monotonic associations of serum Lp(a) with other metabolic risk factors. Binary logistic regression analysis was used to establish the correlation between Lp(a) levels and T2DM risk.

Results: The median Lp(a) concentration was lower in T2DM patients than in controls (16.42 vs. $16.88 \mathrm{mg} / \mathrm{dL}$ ). Based on four quartiles of $L p(a)$ levels, there was a decrease in T2DM risk from 33.7\% (Q1) to 31.96\% (Q4) (P for trend < 0.0001). Then, Lp(a) levels $>28.72 \mathrm{mg} / \mathrm{dL}$ (Q4) were associated with a significantly lower T2DM risk in the unadjusted model $[0.924(0.861,0.992), P=0.030]$. Similar results were obtained in adjusted models 1 [Q4, 0.925 $(0.862,0.993), P=0.031]$ and $2[Q 4,0.919(0.854,0.990), P=0.026]$. Furthermore, in the stratified analysis, Q4 of $L p(a)$ was associated with a significantly lower T2DM risk among men $[0.813(0.734,0.900), P<0.001]$ and those age $>60$ years $[0.819(0.737,0.910), P<0.001]$. In contrast, the low-density lipoprotein cholesterol (LDL-C) levels and coronary heart disease (CHD) did not impact these correlations between $L p(a)$ and diabetes.

Conclusions: There is an inverse association between $L p(a)$ levels and T2DM risk in the Chinese population. Male patients, especially those aged more than 60 years with $\mathrm{Lp}(\mathrm{a})>28.72 \mathrm{mg} / \mathrm{dL}$, are low-risk T2DM individuals, regardless of $L D L-C$ levels and CHD status.
\end{abstract}

\footnotetext{
* Correspondence: skyiadx@hotmail.com

'Department of Cardiovascular Medicine, the Second Affiliated Hospital of Nanchang University, Nanchang, Jiangxi, China

Full list of author information is available at the end of the article
}

C C The Author(s). 2021 Open Access This article is licensed under a Creative Commons Attribution 4.0 International License, which permits use, sharing, adaptation, distribution and reproduction in any medium or format, as long as you give appropriate credit to the original author(s) and the source, provide a link to the Creative Commons licence, and indicate if changes were made. The images or other third party material in this article are included in the article's Creative Commons licence, unless indicated otherwise in a credit line to the material. If material is not included in the article's Creative Commons licence and your intended use is not permitted by statutory regulation or exceeds the permitted use, you will need to obtain permission directly from the copyright holder. To view a copy of this licence, visit http://creativecommons.org/licenses/by/4.0/ The Creative Commons Public Domain Dedication waiver (http://creativecommons.org/publicdomain/zero/1.0/) applies to the data made available in this article, unless otherwise stated in a credit line to the data. 


\section{Introduction}

Lipoprotein (a) $[\mathrm{Lp}(\mathrm{a})]$, discovered in 1963, is plasmabased but has a special structure. It comprises a lipidrich apolipoprotein (apo) B-containing lipoprotein and apo(a) [1]. The apo(a) gene is highly homologous to the plasminogen gene, and it mainly encodes two tricyclic domains (KIV and KV), and an inactive proteasome domain. Plasma $L p(a)$ levels are not changed by the environment, but primarily depend on genetic factors, for example, chromosomal mutation of the LPA gene [2] Elevated $\mathrm{Lp}(\mathrm{a})$ levels exert strong proatherogenic and prothrombotic effects contributing to lifelong elevated risks of cardiovascular disease (CVD), stroke, and valvular aortic stenosis [3]. For people with a moderate to a high risk of CVD / coronary heart disease (CHD), Lp(a) should be screened and maintained below $50 \mathrm{mg} / \mathrm{dL}$ [4]. The 2018 National Heart, Lung, and Blood Institute (NHLBI) Working Group suggested that Lp(a) > $30 \mathrm{mg} /$ dl $(75 \mathrm{nmol} / \mathrm{l})$ or $50 \mathrm{mg} / \mathrm{dl}(100-125 \mathrm{nmol} / \mathrm{l})$ be considered as "elevated Lp(a)" or "hyperlipoproteinemia(a)". This implies that, globally, more than 1 billion people have elevated Lp(a) levels and are at a high risk of CVD and aortic stenosis. Guidelines and consensus statements have been published with recommendations for lowering the Lp(a)-mediated risk of CVD [3].

The estimated incidence rates of diabetes and prediabetes among Chinese adults are $11.6 \%$ (113.9 million) and 50.1\% (493.4 million), respectively, which underscore diabetes as an important public health issue in China [5]. Type 2 diabetes mellitus (T2DM) accounts for most diabetes cases. The global prevalence of diabetes has been on the rise, and is projected to continue increasing in the coming decades [6]. Since T2DM patients are susceptible to CVD, early reports suggested a similar correlation between T2DM and Lp(a) levels. For example, it has been shown that $\mathrm{Lp}(\mathrm{a})$ is closely associated with the progression of intima thickness in T2DM [7]. However, some case-control studies have not reported binding conclusions [8-10]. Several large-scale cohort studies have shown an inverse association between T2DM risk and Lp(a) levels, which has not been validated through Mendelian randomization trials [1113]. A limited number of studies have explored this association in Asian populations, with inconsistent results $[14,15]$. Therefore, this study aimed at exploring the association between $\mathrm{Lp}$ (a) concentrations and T2DM, and to evaluate potential modification factors in the Chinese population.

\section{Methods}

\section{Study participants}

Electronic medical records of the first hospitalized patients at the Second Affiliated Hospital of Nanchang University between July 2006 and June 2017 were retrospectively reviewed. Notably, 5198 patients aged below 20 years, 13,089 undiagnosed patients, and 14,691 patients with severe liver and renal insufficiency were excluded. Ultimately, a total of 9248 T2DM patients and 18,496 controls were included based on 1:2 matched on sex, age, current smoking status, current alcohol consumption status, body mass index (BMI), CHD, and hypertension following principle of the propensity score matching (PSM) method (Fig. 1). In addition, this study only included patients with an estimated glomerular filtration rate $(\mathrm{eGFR})>60 \mathrm{~mL} /\left(\mathrm{min} \cdot 1.73 \mathrm{~m}^{2}\right)$. Ethical approval for this study was obtained from the institutional review board of the Second Affiliated Hospital of Nanchang University, China.

\section{Clinical and laboratory data}

General information, including age, sex, height, weight, smoking, systolic blood pressure (SBP), alcohol consumption, BMI, and diastolic blood pressure (DBP), was recorded. Recorded laboratory data included levels of high-sensitivity C-reactive protein (hsCRP), neutrophil absolute value, total cholesterol (TC), neutrophillymphocyte ratio (NLR), prealbumin, low-density lipoprotein cholesterol (LDL-C), platelet-to-lymphocyte ratio (PLR), homocysteine (HCY), uric acid (UA), triglyceride (TG), high-density lipoprotein cholesterol (HDL-c), Lp(a), albumin, absolute value of lymphocytes, glycosylated hemoglobin (HbA1c), fibrinogen, creatinine, eGFR, fasting plasma glucose (FPG), apoA, and apoB.

\section{Lp(a) measurement}

Fresh serum was obtained from patients who had fasted for more than $8 \mathrm{~h}$. Then, the Lp(a) Assay Kit (Latex Enhanced Immunoturbidimetric Method, Beijingantu Inc., China) was used to measure $\mathrm{Lp}$ (a) concentrations in human serum. The normal reference range of $\mathrm{Lp}(\mathrm{a})$ is from 0 to $3000 \mathrm{mg} / \mathrm{dl}$. Test principle of the method is that $\mathrm{Lp}(\mathrm{a})$ reacts with mouse anti-human lipoprotein (a) monoclonal antibody-coated on latex granules and becomes turbid. Measurement of reaction absorbance was recorded at 570 $\mathrm{nm}$ and was then correlated with the Lp(a) concentration.

\section{Definitions of T2DM, hypertension, and CHD}

In this study, T2DM was defined according to Classification and Diagnosis of Diabetes: Standards of Medical Care in Diabetes-2021: i. FPG $\geq 126 \mathrm{mg} / \mathrm{dL}(7.0 \mathrm{mmol} / \mathrm{L})$ after $8 \mathrm{~h}$ of fasting. ii. Two hours postprandial blood glucose $\geq 200 \mathrm{mg} /$ $\mathrm{dL}(11.1 \mathrm{mmol} / \mathrm{L})$ during the oral glucose tolerance test. Iii. $\mathrm{HbA} 1 \mathrm{C} \geq 6.5 \%$ [16]. Repeated SBP > $140 \mathrm{mmHg}$ and/or DBP $>90 \mathrm{mmHg}$ (at least 3 times) in the clinic was diagnosed as hypertension [17]. CAD diagnosis was based on coronary angiography (CAG), with confirmation being done if at least one coronary artery or its main branch had diameter stenosis $>50 \%[18]$. 


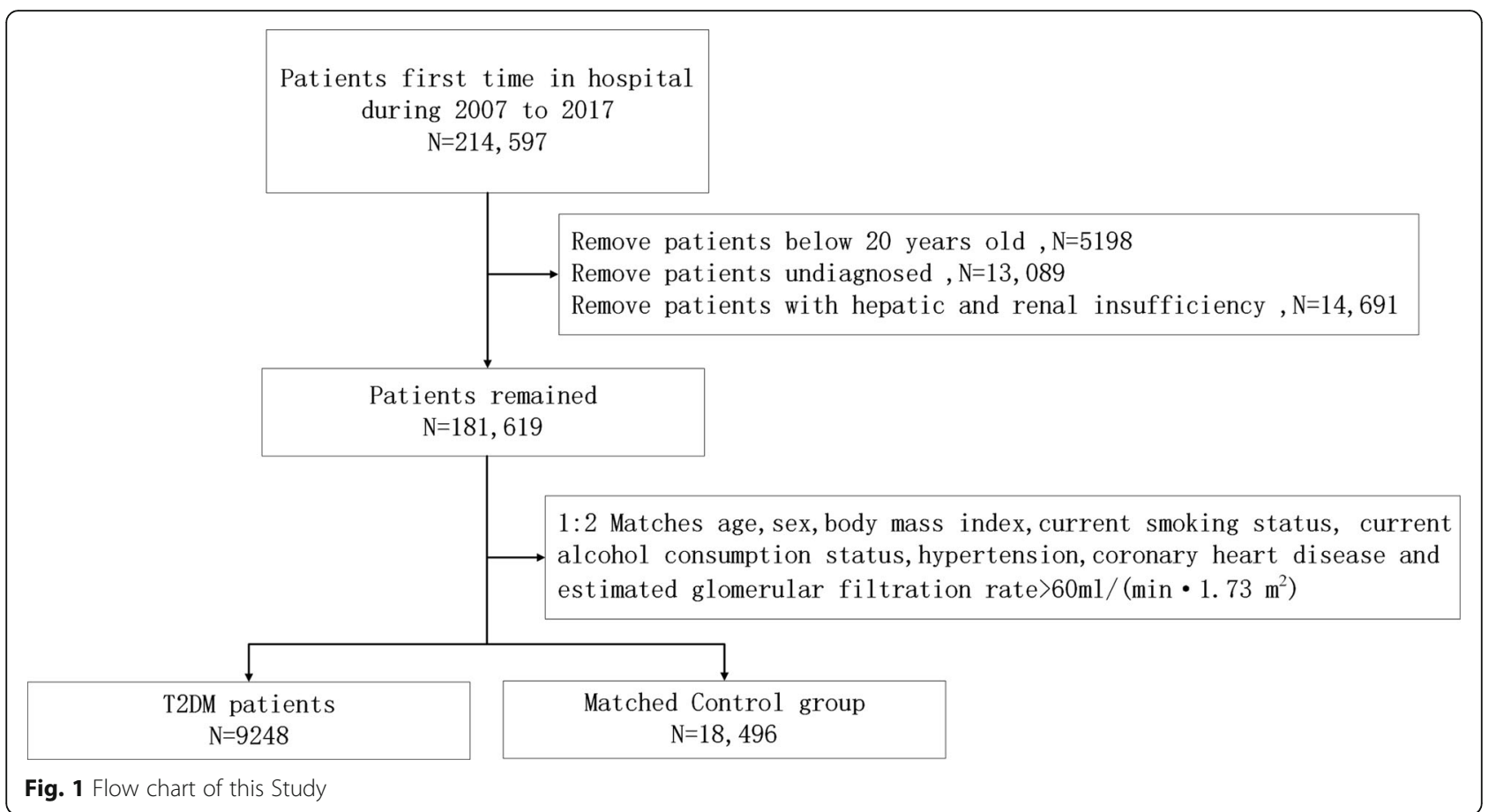

\section{Statistical analysis}

PSM is a statistical method for screening treatment and control groups so that the research subjects are comparable in clinical indicators for the purpose of balancing covariates and reducing bias. PSM establishes whether treatment can be used as a response variable and confounding variables as covariates to construct a regression model. The model estimates the propensity score for each object with ranges of between 0 and 1 , representing the probability of the subject being classified to the treatment group. Therefore, propensity scores are used to balance the distribution of covariates between the treatment and control groups.

Regarding baseline characteristics, continuous variables are presented as medians (interquartile range $[I Q R])$, and Mann-Whitney $U$ tests were used because the normality test showed that all variables exhibited nonnormality. Categorical variables are presented as frequencies and percentages (\%) and were compared using chi-square tests. The Lp(a) levels were divided into four quartiles: quartile 1 (Q1), $0-8.90 \mathrm{mg} / \mathrm{dl}$; quartile $2(\mathrm{Q} 2)$, $8.90-16.74 \mathrm{mg} / \mathrm{dl}$; quartile 3 (Q3), $16.74-28.72 \mathrm{mg} / \mathrm{dl}$; and quartile $4(\mathrm{Q} 4),>28.72 \mathrm{mg} / \mathrm{dl}$. The Spearman rankorder correlation coefficients were used to evaluate the strength and direction of the monotonic associations between $\mathrm{Lp}(\mathrm{a})$ and other factors. In addition, the correlation between $\mathrm{Lp}(\mathrm{a})$ levels and T2DM was analyzed by binary logistic regression analysis. For these matched case-control data, the odds ratios (ORs) and 95\% confidence intervals $(95 \% \mathrm{CIs})$ were calculated by univariate and multivariate logistic regression models. In model 1 ,
hsCRP and SBP were used in the adjustment; in model 2, creatinine, HCY, TG, LDL-C, HDL-C, plus the factors in model 1 were adjusted for. Furthermore, stratified analyses were conducted by age ( $\leq 60$ and $>60$ years), sex (men and women), LDL-C levels $(\leq 130 \mathrm{mg} / \mathrm{dl}$ and $>130$ $\mathrm{mg} / \mathrm{dl}$ ), and the presence or absence of CHD. All tests were two sided, with 0.05 as the significance level. $\mathrm{R}$ (version 3.6.3), SPSS software version 20.0 (SPSS, Inc., Chicago, Illinois), and Python (version 3.7.) were used to perform all statistical analyses.

\section{Results}

\section{Clinical characteristics}

In total, 9248 T2DM patients and 18,496 controls matched on age, sex, current smoking status, current alcohol consumption, BMI, hypertension, CHD, and eGFR $>60 \mathrm{~mL} /\left(\mathrm{min} \cdot 1.73 \mathrm{~m}^{2}\right)$ were randomly selected. Baseline characteristics for the T2DM patients and non-T2DM controls are shown in Table 1. Serum Lp(a) levels were skewed across the 27,744 participants (Figure S1). Briefly, 60 years was the median age after matching. Moreover, the T2DM group exhibited higher TC, LDL$\mathrm{C}$, and TG levels than the control group. Median Lp(a) levels were lower in the T2DM group than in the control (16.42 vs. $16.88 \mathrm{mg} / \mathrm{dl}$ ).

\section{Correlations between $\operatorname{Lp}(\mathrm{a})$ concentrations and other clinical profiles}

Levels of $L p(a)$ exhibited the following: i. significant but very weak positive correlations with most indices, such as LDL-C (r: 0.185), TC (r: 0.113), and apoB (r: 
Table 1 Baseline characteristics of DM and Non-DM cases and controls before and after matching

\begin{tabular}{|c|c|c|c|c|c|c|}
\hline \multirow[t]{2}{*}{ Characteristics } & \multicolumn{2}{|l|}{ Before matching } & \multirow[t]{2}{*}{$P$} & \multicolumn{2}{|l|}{ After matching } & \multirow[t]{2}{*}{$P$} \\
\hline & Control & T2DM & & Control & T2DM & \\
\hline Number & 171,532 & 10,087 & & 18,496 & 9248 & \\
\hline Age, years & $60.000[49.000,70.000]$ & $61.000[53.000,69.000]$ & $\begin{array}{l}< \\
0.001\end{array}$ & $60.0[52.0,68.0]$ & $60.0[52.0,68.0]$ & 0.958 \\
\hline Male, n (\%) & $93,900(54 \%)$ & $5325(52 \%)$ & $\begin{array}{l}< \\
0.001\end{array}$ & $9670(52 \%)$ & $4832(52 \%)$ & 0.959 \\
\hline Current smoking status, n (\%) & $113,057(65 \%)$ & 7917 (78\%) & $\begin{array}{l}< \\
0.001\end{array}$ & $14,514(78 \%)$ & $7262(78 \%)$ & 0.918 \\
\hline $\begin{array}{l}\text { Current alcohol consumption status, } \mathrm{n} \\
(\%)\end{array}$ & $9719(5 \%)$ & $645(6 \%)$ & 0.002 & $1125(6 \%)$ & $594(6 \%)$ & 0.267 \\
\hline CHD, n (\%) & $16,814(9 \%)$ & $526(5 \%)$ & $\begin{array}{l}< \\
0.001\end{array}$ & $904(4 \%)$ & $456(4 \%)$ & 0.875 \\
\hline Hypertension, n (\%) & $55,313(32 \%)$ & $3916(38 \%)$ & $\begin{array}{l}< \\
0.001\end{array}$ & $6847(37 \%)$ & $3423(37 \%)$ & 0.993 \\
\hline BMI & $22.769[21.214,24.347]$ & $23.723[22.276,25.073]$ & $\begin{array}{l}< \\
0.001\end{array}$ & $23.73[22.27,25.07]$ & $23.74[22.28,25.10]$ & 0.425 \\
\hline Lp(a), mg/dL & $17.270[9.170,29.720]$ & $16.750[8.920,28.580]$ & 0.001 & $16.88[8.92,29.07]$ & $16.42[8.8,28.0]$ & 0.015 \\
\hline $\mathrm{SBP}, \mathrm{mmHg}$ & $\begin{array}{l}126.000 \\
{[119.660,136.000]}\end{array}$ & $\begin{array}{l}130.000 \\
{[120.000,140.000]}\end{array}$ & $\begin{array}{l}< \\
0.001\end{array}$ & $\begin{array}{l}127.83 \\
{[120.0,138.0]}\end{array}$ & $\begin{array}{l}129.91 \\
{[120.0,139.25]}\end{array}$ & $\begin{array}{l}< \\
0.001\end{array}$ \\
\hline $\mathrm{DBP}, \mathrm{mmHg}$ & $76.000[70.000,80.000]$ & $77.310[72.680,81.000]$ & $\begin{array}{l}< \\
0.001\end{array}$ & $76.54[70.0,80.92]$ & $77.3[72.83,81.0]$ & $<0.001$ \\
\hline $\mathrm{TC}, \mathrm{mmol} / \mathrm{L}$ & $4.290[3.620,5.000]$ & $4.520[3.840,5.250]$ & $\begin{array}{l}< \\
0.001\end{array}$ & $4.46[3.77,5.16]$ & $4.53[3.86,5.25]$ & $\begin{array}{l}< \\
0.001\end{array}$ \\
\hline $\mathrm{TG}, \mathrm{mmol} / \mathrm{L}$ & $1.190[0.870,1.710]$ & $1.420[1.010,2.070]$ & $\begin{array}{l}< \\
0.001\end{array}$ & $1.34[0.96,1.93]$ & $1.41[1.0,2.07]$ & $\begin{array}{l}< \\
0.001\end{array}$ \\
\hline $\mathrm{HDL}-\mathrm{c}, \mathrm{mmol} / \mathrm{L}$ & $1.050[0.860,1.270]$ & $1.010[0.840,1.210]$ & $\begin{array}{l}< \\
0.001\end{array}$ & $1.04[0.86,1.25]$ & $1.01[0.85,1.22]$ & $\begin{array}{l}< \\
0.001\end{array}$ \\
\hline $\mathrm{LDL}-\mathrm{c}, \mathrm{mmol} / \mathrm{L}$ & $2.520[1.990,3.110]$ & $2.690[2.120,3.300]$ & $\begin{array}{l}< \\
0.001\end{array}$ & $2.64[2.09,3.22]$ & $2.7[2.14,3.3]$ & $\begin{array}{l}< \\
0.001\end{array}$ \\
\hline ApoA, mmol/L & $1.050[0.880,1.230]$ & $1.050[0.900,1.220]$ & 0.081 & $1.06[0.9,1.24]$ & $1.05[0.9,1.22]$ & 0.096 \\
\hline ApoB, mmol/L & $0.770[0.640,0.930]$ & $0.830[0.690,1.000]$ & $\begin{array}{l}< \\
0.001\end{array}$ & $0.81[0.67,0.96]$ & $0.83[0.69,1.0]$ & $<0.001$ \\
\hline $\mathrm{eGFR}, \mathrm{mL} /\left(\min \cdot 1.73 \mathrm{~m}^{2}\right)$ & $97.483[81.653,113.860]$ & $\begin{array}{l}101.990 \\
{[83.391,120.894]}\end{array}$ & $\begin{array}{l}< \\
0.001\end{array}$ & $\begin{array}{l}97.81 \\
{[85.03,112.20]}\end{array}$ & $\begin{array}{l}104.85 \\
{[88.69,122.85]}\end{array}$ & $\begin{array}{l}< \\
0.001\end{array}$ \\
\hline Fasting Glucose, mmol/L & $4.990[4.510,5.740]$ & $7.820[5.940,11.030]$ & $\begin{array}{l}< \\
0.001\end{array}$ & $5.11[4.62,5.87]$ & $7.88[5.99,11.03]$ & $\begin{array}{l}< \\
0.001\end{array}$ \\
\hline $\mathrm{HbA} 1 \mathrm{c}, \%$ & $5.713[5.500,6.031]$ & $7.700[6.500,9.800]$ & $\begin{array}{l}< \\
0.001\end{array}$ & $5.79[5.54,6.10]$ & $7.7[6.5,9.86]$ & $\begin{array}{l}< \\
0.001\end{array}$ \\
\hline Creatinine, $\mathrm{mmol} / \mathrm{L}$ & $68.879[57.200,82.610]$ & $65.800[54.080,80.200]$ & $\begin{array}{l}< \\
0.001\end{array}$ & $67.4[56.9,79.0]$ & $63.96[52.9,75.6]$ & $\begin{array}{l}< \\
0.001\end{array}$ \\
\hline $\mathrm{HCY}, \mu \mathrm{mol} / \mathrm{L}$ & $13.447[11.133,16.380]$ & $11.842[9.910,14.452]$ & $\begin{array}{l}< \\
0.001\end{array}$ & $\begin{array}{l}13.090 \\
{[11.10,15.60]}\end{array}$ & $11.57[9.76,13.82]$ & $\begin{array}{l}< \\
0.001\end{array}$ \\
\hline hsCRP, mg/dL & $4.362[2.000,15.492]$ & $4.186[2.365,10.414]$ & 0.628 & $3.85[2.04,11.53]$ & $3.917[2.3,9.03]$ & 0.317 \\
\hline
\end{tabular}

Continuous variables presented as median $(25,75 \%)$

ApoA, apolipoprotein A; ApoB, apolipoprotein B; BMI, body mass index; CHD, coronary heart disease; DBP, diastolic blood pressure; eGFR, estimated glomerular filtration rate; HbA1c, glycosylated hemoglobin; hsCRP, high-sensitivity C-reactive protein; HCY, homocysteine; HDL-c, high density lipoprotein cholesterol; LDL-c, low density lipoprotein cholesterol; Lp(a), lipoprotein (a); SBP, systolic blood pressure; TC, total cholesterol; TG, triglyceride

0.136) (Table S1); ii. significant but very weak negative correlations with TG (r: -0.073), albumin (r: 0.027), eGFR ( $\mathrm{r}:-0.050)$, HCY (r: - 0.021), and fasting glucose (r: - 0.037) (Table S1); iii. Significantly positive correlations with CHD (r: 0.019), ischemic stroke (r: 0.047), and hypertension ( $\mathrm{r}: 0.018$ ); iv. Negative correlations with T2DM (r: - 0.012) and hypertriglyceridemia ( $r$ : - 0.097) (Table S1); v. significant positive correlations with inflammatory markers, such as hsCRP (r: 0.053), NLR (r: 0.054), and PLR (r: 0.111). 


\section{Lp(a) and T2DM risk}

Based on the four Lp(a) quartiles, a decreasing trend in the incidence of T2DM was found, from 33.7\% (Q1) to $31.96 \%(\mathrm{Q} 4)$ ( $P$ for trend $<0.0001$ ) (Figure S2A), and an increasing trend in the incidence of CHD from $4.57 \%$ (Q1) to $5.47 \%(\mathrm{Q} 4)$ (Figure S2B). A decreasing trend in the incidence of T2DM combined T2DM with CHD was found, from 1.74\% (Q1) to 1.54\% (Q4) (Figure S2C). A binary conditional logistic regression model was used to determine whether $\mathrm{Lp}$ (a) concentrations were independently associated with the onset of T2DM (Table 2). Using an unadjusted model, the ORs and 95\% CIs for Lp(a) quartiles 2-4 were found to be 1.020 (0.951, $1.094), 0.993(0.925,1.065)$, and $0.924(0.861,0.992)$, respectively. After adjusting for hsCRP and SBP in model 1 , similar results to those in the unadjusted group [Q4, 0.925 (0.862, 0.993), $P=0.031]$ were obtained. Furthermore, after adjusting for the factors included in model 1 plus creatinine, homocysteine, TG, LDL-C, and HDL-C (Table 2), similar results to model 1 were obtained as follows: Lp(a) was significantly associated with T2DM risk with ORs and 95\% CI in the Q4 group [0.919 (0.854, $0.990), P=0.026]$. In the stratified analysis, $\mathrm{Q} 4$ of $\mathrm{Lp}(\mathrm{a})$ had a significantly lower T2DM risk in men [0.813 (0.734, 0.900), $P<0.001$ ] (Fig. 2A) and the elderly population aged $>60$ years $[0.819(0.737,0.910), P<0.001]$ (Fig. 2D). Conversely, LDL-C levels and CHD had no impact on the correlation between $\mathrm{Lp}(\mathrm{a})$ and T2DM (Fig. 2B and C).

\section{Discussion}

This study found that, at $\mathrm{Lp}$ (a) concentrations $>28.72$ $\mathrm{mg} / \mathrm{dL}$, there was a significant inverse correlation between $\mathrm{Lp}(\mathrm{a})$ concentrations and T2DM in the Chinese population. However, this was not the case in all populations. In particular, there was a significant inverse association between elevated Lp(a) levels and T2DM only in men and individuals aged above 60 years, and these relationships were not impacted by LDL-C levels and CHD status.
Studies on the relationship between Lp(a) levels and diabetes have not established conclusive findings $[9,19$ 22]. For instance, Wang et al. found that $\mathrm{Lp}(\mathrm{a})$ levels in diabetic patients was significantly higher than those in nondiabetic controls in the Chinese population [21]. In contrast, another prospective cohort study by Muhanhali et al. found that Q1 of $\mathrm{Lp}(\mathrm{a})$ levels (median $8.44 \mathrm{mg} / \mathrm{dL}$ ) had a $71 \%$ higher risk of T2DM compared to the overall $\mathrm{Lp}$ (a) median level of $74.93 \mathrm{mg} / \mathrm{dL}$ [23]. Other studies have reported no correlation between Lp(a) levels and T2DM. Liu et al. found that this association was evident at some $\mathrm{Lp}(\mathrm{a})$ concentration range but that the relationships could be attributed to chance and not an actual association [14]. Elsewhere, a Mendelian randomization study revealed that low $\mathrm{Lp}(\mathrm{a})$ levels do not have causal correlation with diabetes. However, a causal relationship between large $\mathrm{Lp}(\mathrm{a})$ subtype size and T2DM was found [12]. This study found that elevated Lp(a) levels $(>28.72$ $\mathrm{mg} / \mathrm{dL}$ ) potentially lowered T2DM risk, but only in men and those aged above 60 years. In tandem with findings in this study, a recent study found that the prevalence and incidence rates of T2DM increased with decreasing baseline levels of $\mathrm{Lp}(\mathrm{a})$ [24].

This study also found a significant inverse relationship between elevated Lp(a) levels and T2DM in men and in individuals aged over 60 years. These results implied that not all populations exhibit an inverse relationship between elevated $\mathrm{Lp}(\mathrm{a})$ and T2DM risk. Similar findings were reported by Boronat et al. who found a significant reduction in the risk of age-related diabetes at $\mathrm{Lp}(\mathrm{a})>$ $46 \mathrm{mg} / \mathrm{dL}$ [25]. Furthermore, in this study, men with T2DM exhibited lower Lp(a) levels than women (15.97 vs. $16.94 \mathrm{mg} / \mathrm{dL}$, respectively, $P=0.001)$ ); however, only men exhibited a significant negative correlation between Lp(a) and glucose levels (men, $-0.0555 P<0.001$; Woman $\mathrm{r}$ : $-0.0146, P=0.0919$ ) (Fig. 3). In contrast, in the nondiabetic population, there was no significant difference in median $\mathrm{Lp}$ (a) levels between men and women (16.0 vs. $16.82 \mathrm{mg} / \mathrm{dL}, P=0.246$ ). The findings in this study are consistent with those from a previous study

Table 2 Odd ratios (95\% confidence intervals) for T2DM and Lp(a) concentration

\begin{tabular}{|c|c|c|c|c|c|c|}
\hline \multirow[t]{2}{*}{ Group } & \multicolumn{2}{|l|}{ Unadjusted model } & \multicolumn{2}{|l|}{ Model1 } & \multicolumn{2}{|l|}{ Model2 } \\
\hline & OR $(95 \% \mathrm{Cl})$ & $P$ value & OR $(95 \% \mathrm{Cl})$ & $P$ value & OR $(95 \% \mathrm{Cl})$ & $P$ value \\
\hline Q1 & Reference & & Reference & & Reference & \\
\hline Q2 & $1.020[0.951,1.094]$ & 0.580 & $1.013[0.944,1.087]$ & 0.712 & $1.009[0.939,1.085]$ & 0.798 \\
\hline Q3 & $0.993[0.925,1.065]$ & 0.835 & $0.987[0.920,1.059]$ & 0.710 & $0.981[0.912,1.055]$ & 0.597 \\
\hline Q4 & $0.924[0.861,0.992]$ & 0.030 & $0.925[0.862,0.993]$ & 0.031 & $0.919[0.854,0.990]$ & 0.026 \\
\hline Per Q effect & $0.974[0.953,0.996]$ & & $0.974[0.953,0.996]$ & & $0.969[0.947,0.992]$ & \\
\hline$P$ for trend & & 0.022 & & 0.023 & & 0.009 \\
\hline
\end{tabular}

Model1: adjusted for high-sensitivity C-reactive protein, systolic blood pressure

Model 2: adjusted for model 1 plus, creatinine, homocysteine, low density lipoprotein, high density lipoprotein, triglyceride

The 25 th, 50th, and 75th percentile cut-off points for corresponding $\mathrm{Lp}(\mathrm{a})$ are $8.90,16.74$, and $28.72 \mathrm{mg} / \mathrm{dL}$, respectively 


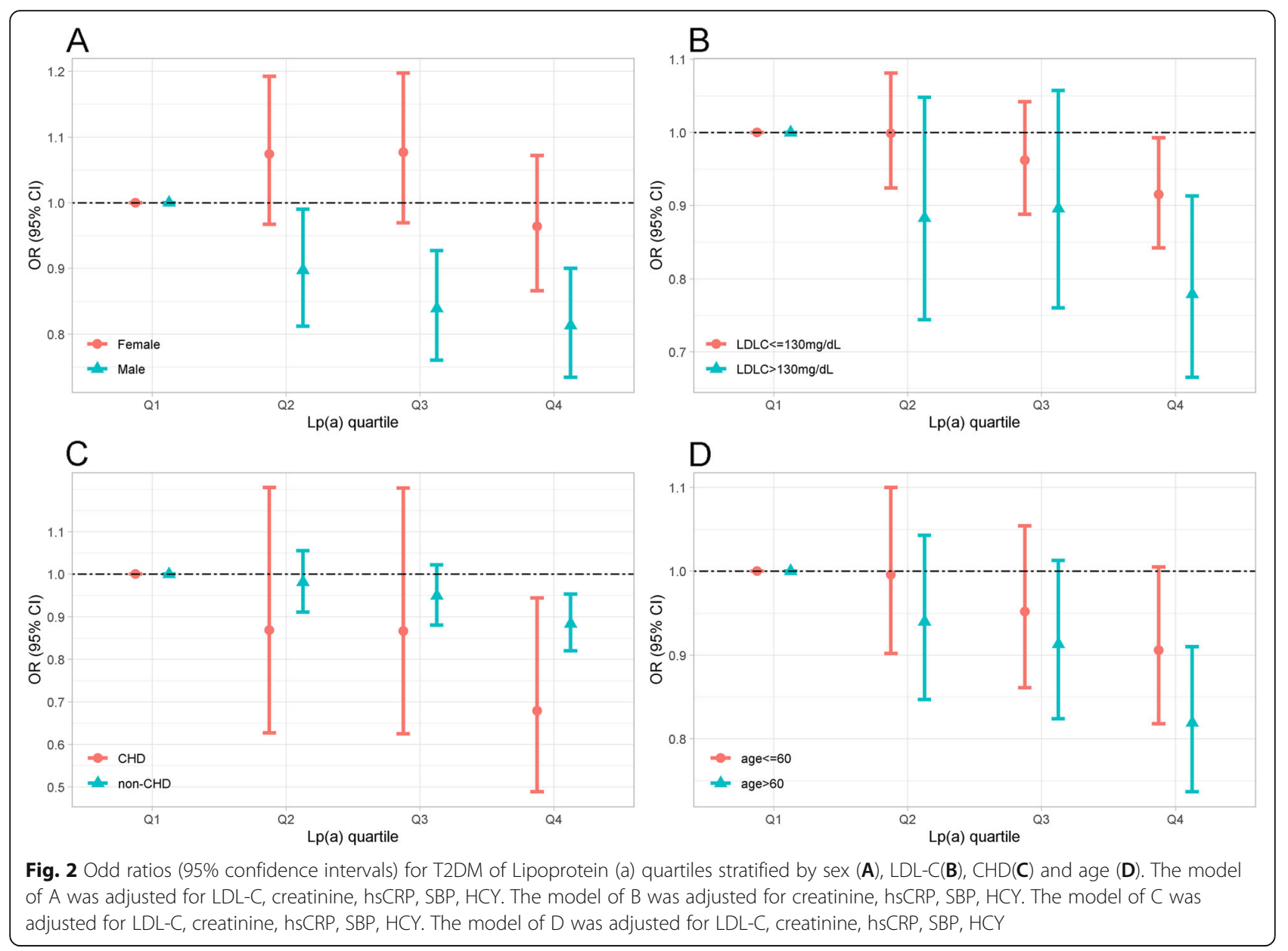

performed at Tehran Medical University [22], which found that women with T2DM had increased Lp(a) levels regardless of menopausal status. A Korean study [26] also found that women had significantly higher $\mathrm{Lp}$ (a) levels when compared to than men (median: 13.2 vs. $10.6 \mathrm{mg} / \mathrm{dL}$ ). These differences could be attributed to various factors, such as ethnic differences associated with genetic differences that may impact Lp(a) levels. Hungarian individuals were found to have lower median plasma levels than Tyrolean individuals ( 8.3 vs. $14.1 \mathrm{mg} /$ $\mathrm{dL})$, whereas Chinese individuals had lower median plasma levels than Sudanese individuals (7.2 vs. $45.7 \mathrm{mg} /$ dL). In Asian populations, significant heterogeneity exists. The median $L p(a)$ level in Indian men was found to be significantly higher than that in Chinese men (35 vs. $19 \mathrm{mg} / \mathrm{dL}, P=0.0001)$. Among women, there were no statistically significant differences between Indian and Chinese individuals $(41 \mathrm{mg} / \mathrm{dl}$ vs. $27 \mathrm{mg} / \mathrm{dl}, P=0.1642)$ $[27,28]$. Factors that potentially influence $\mathrm{Lp}(\mathrm{a})$ levels, such as insulin therapy alone, may also elevate $\operatorname{Lp}(\mathrm{a})$ levels, which were found to be twice as high in nonright-handed patients as in right-handed patients [29, 30]. Therefore, differences in age and sex should be considered in actual clinical practice. This study found that elevated Lp(a) levels lowered the risk of T2DM. Future large well-designed prospective cohort studies are needed to validate these results.

The mechanisms through which serum Lp(a) levels are associated with diabetes risk remain elusive. Generally, studies on inverse relationships have reported that $\operatorname{Lp}(\mathrm{a})$ levels are inversely correlated with insulin resistance. A Korean study [31] revealed that $\mathrm{Lp}(\mathrm{a})$ levels were significantly negatively associated with fasting insulin levels, insulin resistance (IR), and insulin secretion (IS). Among patients with low $\mathrm{Lp}(\mathrm{a})$ levels, a significantly higher risk of diabetes development was reported in patients with IR alone than in patients with IS impairment alone. A similar conclusion was found in another study that assessed the Turkish population [32]. Moreover, T2DM individuals present with hyperinsulinemia induced by peripheral insulin tolerance. Since elevated insulin concentrations impede the production of posttranscriptional apoA in liver cells, plasma $\mathrm{Lp}(\mathrm{a})$ levels are consequently suppressed [33]. However, the specific mechanisms should be further elucidated. 


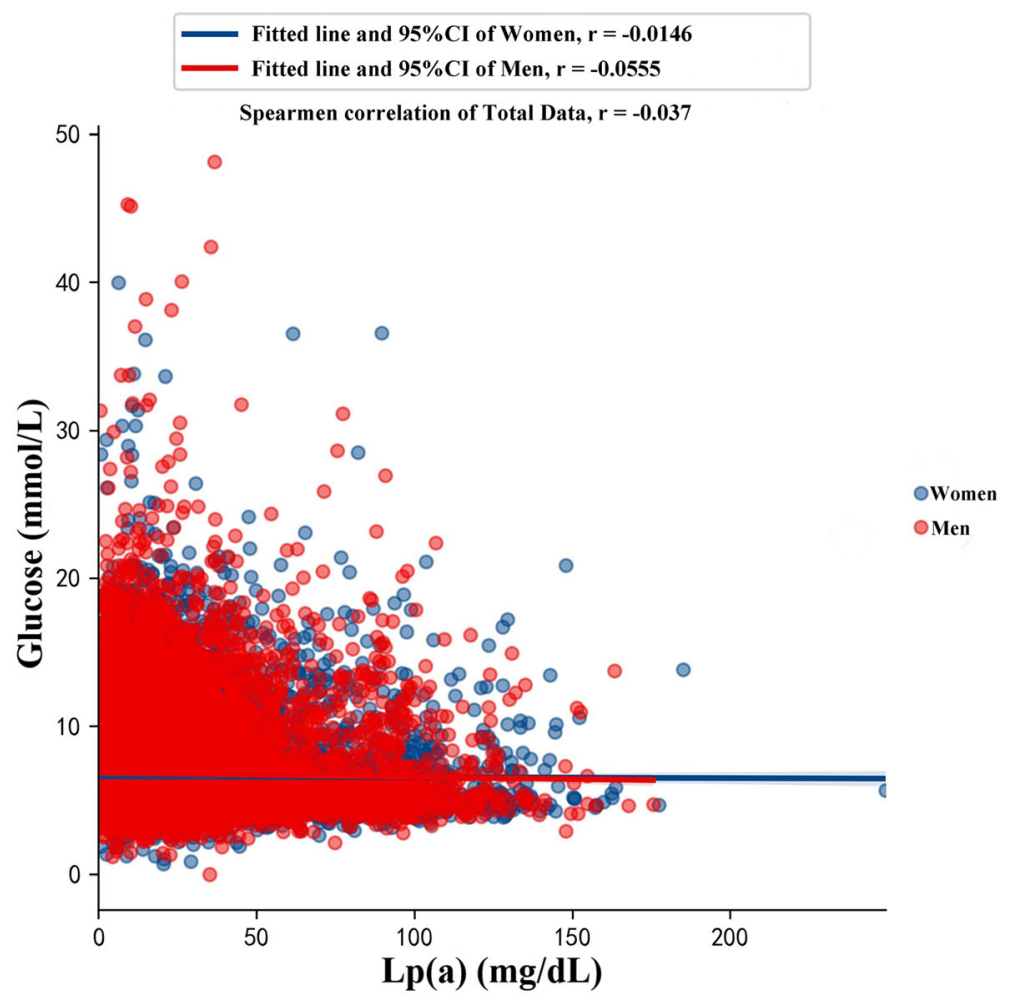

Fig. 3 Simple scatter plot and fit line with $95 \%(C l)$ of the correlation coefficent in Spearman correlation of $L p(a)$ and glucose

Inconsistencies in measurement methods can result in differences in mean serum Lp(a) levels. This potentially explains why associations between $\mathrm{Lp}(\mathrm{a})$ and T2DM vary among studies. Various drugs have an effect on Lp(a) levels. Proprotein convertase subtilisin/kexin type 9 (PCSK9) inhibitors have been confirmed to reduce Lp(a) levels [34]. Treatment with extended-release nicotinic acid has been significantly associated with suppressed Lp(a) levels [35]. Other non-lipid lowering drugs, such as raloxifene have also been shown to have an effect on $\mathrm{Lp}$ (a) levels. Oral raloxifene treatment significantly reduced plasma $\mathrm{Lp}$ (a) levels, especially in postmenopausal women [36]. In addition, some natural products affect plasma Lp(a) levels. A positive clinical significance of flaxseed supplementation for patients whose plasma Lp(a) levels remained high after statin therapy has been reported [37]. Unfortunately, the database used in the present study did not contain data on drugs used by the included patients. Future studies should aim to confirm whether drugs that influence Lp(a) levels can impact the relationship between $\mathrm{Lp}(\mathrm{a})$ and T2DM.

\section{Study strength and limitations}

This is a large-scale, well-matched retrospective cohort study on the relationships between $\mathrm{Lp}(\mathrm{a})$ concentration and T2DM in a Chinese population. It shows that there is an inverse association. In addition, this effect was significant only in aged patients ( $>60$ years old) and men, and this relationship was not altered by LDL-C levels and CHD status.
However, there are some limitations to this study. First, as a retrospective study, This study could only assess the correlation between $\mathrm{Lp}$ (a) levels and T2DM risk but not the causal relationship. Second, the data used in this study were based on hospital and clinical patients, which may have introduced residual confounding factors. Regression study designs are easily influenced by such confounding factors, which may exaggerate or weaken the correlation of existing variables. To reduce the influence of confounding factors, definite diabetic risk factors (excluding multicollinearity among covariates) were incorporated into logistic models for stratified analysis in this study. Third, recent studies have reported that Lp(a) levels are likely to be affected by statins [38], but the data on whether this study participants were taking lipid-lowering drugs or had been treated with some natural products was missing, which may have introduced a bias into this study.

\section{Conclusion}

In conclusion, there is an inverse association between Lp(a) levels and T2DM risk. This effect is significant only in aged patients ( $>60$ years old) and men. Such an inverse correlation provides some evidence for a deeper understanding of $\mathrm{Lp}(\mathrm{a})$ in diabetic patients. Therefore, male patients who are more than 60 years of age with $\mathrm{Lp}$ (a) levels greater than $28.72 \mathrm{mg} / \mathrm{dL}$ should be considered to be less at risk of T2DM, regardless of LDL-C levels and CHD status. 


\section{Abbreviations}

apoA: apolipoprotein A; apoB: apolipoprotein B; BMI: Body mass index; CAG: Coronary angiography; CVD: Cardiovascular disease; CHD: Coronary heart disease; hsCRP: high-sensitivity C-reactive protein; DBP: Diastolic blood pressure; eGFR: glomerular filtration rate; GLU: Glucose; HbA1c: Glycosylated hemoglobin; HCY: Homocysteine; HDL:-c: High density lipoprotein cholesterol; IQR: Interquartile range; IR: Insulin resistance; IS: Insulin secretion; LDL-C: low density lipoprotein cholesterol; Lp(a): Lipoprotein (a); NHLBI: National Heart, Lung, and Blood Institute; NLR: NeutrophilLymphocyte Ratio; PCSK9: Proprotein convertase subtilisin/kexin type 9; PLR: Platelet-to-lymphocyte ratio; PSM: Propensity Score Matching; SBP: Systolic blood pressure; TC: Total cholesterol; TG: Triglyceride; T2DM: Type 2 diabetes mellitus; UA: Uric acid

\section{Supplementary Information}

The online version contains supplementary material available at https://doi. org/10.1186/s12944-021-01504-x.

\section{Additional file 1.}

\section{Acknowledgements}

We thank Extreme Smart Analysis platform (https://www.xsmartanalysis.com/) for its analysis assistance.

\section{Authors' contributions}

F.Q.A wrote the main manuscript text, H.L.J. prepared figures and tables, X. Y and Y.Y.P. did the statistical analysis, J.L. revised the manuscript. All authors reviewed the manuscript. The author(s) read and approved the final manuscript.

\section{Funding}

This work was supported by grants from the National Natural Science Foundation for Young Scientists of China (No. 81700792). National Key R\&D Program of China, (2018YFC1312902). The 03-special project of Jiangxi science and Technology Department (Grant No. 20193ABC03A043). The Natural Science Foundation of Jiangxi Province for Distinguished Young Scholars of China (Grant No. 2018ACB21035), the Natural Science Foundation of Jiangxi Province for Young Scientists of China (Grant No. 20171BAB215004), Nanchang University youth teacher training fund (Grant No. PY201821).

\section{Availability of data and materials}

The datasets used and/or analyzed during the current study available from the corresponding author on reasonable request.

\section{Declarations}

\section{Ethics approval and consent to participate}

Approval for the study protocol was issued by the institutional review board of the Second Affiliated Hospital of Nanchang University, China. Because this is a retrospectively observe study, the informed consent waiver was obtained by The Second Affiliated Hospital of Nanchang University Medical Research Ethics Committee. We confirm that all methods were carried out in accordance with the guidelines and regulations of Declaration of Helsinki.

\section{Consent for publication}

All authors have given permission to submit, and there are no conflicts of interests to report

\section{Competing interests}

The Authors declare that there is no conflict of interest.

\section{Author details}

${ }^{1}$ Department of Cardiovascular Medicine, the Second Affiliated Hospital of Nanchang University, Nanchang, Jiangxi, China. ${ }^{2}$ Department of Nursing, Science and Technology College of Jiangxi University of Traditional Chinese Medicine, Nanchang, China. ${ }^{3}$ Department of Medical Big Data Center, the Second Affiliated Hospital of Nanchang University, Nanchang, Jiangxi, China.
Received: 15 April 2021 Accepted: 15 July 2021

Published online: 27 July 2021

\section{References}

1. Tsimikas S. A test in context: lipoprotein(a): diagnosis, prognosis, controversies, and emerging therapies. J Am Coll Cardiol. 2017;69(6):692711. https://doi.org/10.1016/j.jacc.2016.11.042.

2. Wilson DP, Koschinsky ML, Moriarty PM. Expert position statements: comparison of recommendations for the care of adults and youth with elevated lipoprotein(a). Current opinion in endocrinology, diabetes, and obesity. 2021;28(2):159-73. https://doi.org/10.1097/MED.0000000000000624.

3. Tsimikas S, Fazio S, Ferdinand KC, Ginsberg HN, Koschinsky ML, Marcovina $\mathrm{SM}$, et al. NHLBI working group recommendations to reduce lipoprotein(a)mediated risk of cardiovascular disease and aortic stenosis. J Am Coll Cardiol. 2018;71(2):177-92. https://doi.org/10.1016/j.jacc.2017.11.014.

4. Nordestgaard BG, Chapman MJ, Ray K, Borén J, Andreotti F, Watts GF, et al. Lipoprotein(a) as a cardiovascular risk factor: current status. Eur Heart J. 2010;31(23):2844-53. https://doi.org/10.1093/eurheartj/ehq386.

5. Xu Y, Wang L, He J, Bi Y, Li M, Wang T, et al. Prevalence and control of diabetes in Chinese adults. Jama. 2013;310(9):948-59. https://doi.org/10.1 001/jama.2013.168118

6. Saeedi P, Petersohn I, Salpea P, Malanda B, Karuranga S, Unwin N, et al. Global and regional diabetes prevalence estimates for 2019 and projections for 2030 and 2045: Results from the International Diabetes Federation Diabetes Atlas, 9(th) edition. Diabetes Res Clin Pract. 2019;157. https://doi. org/10.1016/j.diabres.2019.107843.

7. Boras J, Ljubic S, Car N, Metelko Z, Petrovecki M, Lovrencic MV, et al. Lipoprotein(a) predicts progression of carotid artery intima-media thickening in patients with type 2 diabetes: a four-year follow-up. Wien Klin Wochenschr. 2010;122(5-6):159-64. https://doi.org/10.1007/s00508-010-131 8-0.

8. Durlach V, Gillery P, Bertin E, Taupin JM, Grulet H, Gross A, et al. Serum lipoprotein (a) concentrations in a population of 819 non-insulin-dependent diabetic patients. Diabetes Metab. 1996;22(5):319-23.

9. O'Brien T, Nguyen TT, Harrison JM, Bailey KR, Dyck PJ, Kottke BA. Lipids and $L p(a)$ lipoprotein levels and coronary artery disease in subjects with noninsulin-dependent diabetes mellitus. Mayo Clin Proc. 1994;69(5):430-5. https://doi.org/10.1016/S0025-6196(12)61638-3.

10. Rainwater DL, MacCluer JW, Stern MP, VandeBerg JL, Haffner SM. Effects of NIDDM on lipoprotein(a) concentration and apolipoprotein(a) size. Diabetes. 1994:43(7):942-6. https://doi.org/10.2337/diab.43.7.942.

11. Mora S, Kamstrup PR, Rifai N, Nordestgaard BG, Buring JE, Ridker PM. Lipoprotein(a) and risk of type 2 diabetes. Clin Chem. 2010;56(8):1252-60. https://doi.org/10.1373/clinchem.2010.146779.

12. Kamstrup PR, Nordestgaard BG. Lipoprotein(a) concentrations, isoform size, and risk of type 2 diabetes: a Mendelian randomisation study. Lancet Diabetes Endocrinol. 2013;1(3):220-7. https://doi.org/10.1016/S2213-8587(13)70064-0.

13. Ding L, Song A, Dai M, Xu M, Sun W, Xu B, et al. Serum lipoprotein (a) concentrations are inversely associated with $\mathrm{T} 2 \mathrm{D}$, prediabetes, and insulin resistance in a middle-aged and elderly Chinese population. J Lipid Res. 2015;56(4):920-6. https://doi.org/10.1194/jlr.P049015.

14. Liu C, Xu MX, He YM, Zhao X, Du XJ, Yang XJ. Lipoprotein (a) is not significantly associated with type 2 diabetes mellitus: cross-sectional study of 1604 cases and 7983 controls. Acta Diabetol. 2017:54(5):443-53. https:// doi.org/10.1007/s00592-017-0965-2.

15. Zhang Y, Jin JL, Cao YX, Zhang HW, Guo YL, Wu NQ, et al. Lipoprotein (a) predicts recurrent worse outcomes in type 2 diabetes mellitus patients with prior cardiovascular events: a prospective, observational cohort study. Cardiovasc Diabetol. 2020;19(1):111. https://doi.org/10.1186/s12933-020-01083-8.

16. 2. Classification and Diagnosis of Diabetes. Standards of Medical Care in Diabetes-2021. Diabetes Care. 2021:44(Suppl 1):S15-s33.

17. Unger T, Borghi C, Charchar F, Khan NA, Poulter NR, Prabhakaran D, et al. 2020 International Society of Hypertension Global Hypertension Practice Guidelines. Hypertension (Dallas, Tex : 1979). 2020;75(6):1334-57. https://doi. org/10.1161/HYPERTENSIONAHA.120.15026.

18. Thygesen K, Alpert JS, Jaffe AS, Simoons ML, Chaitman BR, White HD, et al. Third universal definition of myocardial infarction. Circulation. 2012;126(16): 2020-35. https://doi.org/10.1161/CIR.0b013e31826e1058.

19. Habib SS, Aslam M. High risk levels of lipoprotein(a) in Pakistani patients with type 2 diabetes mellitus. Saudi Med J. 2003;24(6):647-51. 
20. Heller FR, Jamart J, Honore P, Derue G, Novik V, Galanti L, et al. Serum lipoprotein(a) in patients with diabetes mellitus. Diabetes Care. 1993;16(5): 819-23. https://doi.org/10.2337/diacare.16.5.819.

21. Wang C, Niu DM, Hu J, Guan XC, Yang W, Wang JJ, et al. Elevated serum $\beta 2$-glycoprotein-I-lipoprotein(a) complexes levels are associated with the presence and complications in type 2 diabetes mellitus. Diabetes Res Clin Pract. 2013;100(2):250-6. https://doi.org/10.1016/j.diabres.2013.03.002.

22. Nakhjavani M, Morteza A, Esteghamati A, Khalilzadeh O, Zandieh A, Safari R. Serum lipoprotein(a) levels are greater in female than male patients with type-2 diabetes. Lipids. 2011;46(4):349-56. https//doi.org/10.1007/s11745-010-3513-1.

23. Muhanhali D, Zhai T, Cai Z, Ling Y. Lipoprotein(a) concentration is associated with risk of type 2 diabetes and cardiovascular events in a Chinese population with very high cardiovascular risk. Endocrine. 2020;69(1): 63-72. https://doi.org/10.1007/s12020-020-02286-5.

24. Schwartz GG, Szarek M, Bittner VA, Bhatt DL, Diaz R, Goodman SG, et al. Relation of lipoprotein(a) levels to incident type 2 diabetes and modification by Alirocumab treatment. Diabetes Care. 2021;44(5):1219-27. https://doi.org/10.2337/dc20-2842.

25. Boronat M, Saavedra P, Pérez-Martín N, López-Madrazo MJ, Rodríguez-Pérez C, Nóvoa FJ. High levels of lipoprotein(a) are associated with a lower prevalence of diabetes with advancing age: results of a cross-sectional epidemiological survey in gran Canaria, Spain. Cardiovascular Diabetol. 2012; 11(1):81. https://doi.org/10.1186/1475-2840-11-81.

26. Jun JE, Kang H, Hwang YC, Ahn KJ, Chung HY, Jeong IK. The association between lipoprotein (a) and carotid atherosclerosis in patients with type 2 diabetes without pre-existing cardiovascular disease: a cross-sectional study. Diabetes Res Clin Pract 2021;171:108622. https://doi.org/10.1016/j.diabres.2020.108622.

27. Sandholzer C, Hallman DM, Saha N, Sigurdsson G, Lackner C, Császár A, et al. Effects of the apolipoprotein(a) size polymorphism on the lipoprotein(a) concentration in 7 ethnic groups. Hum Genet. 1991;86(6):60714. https://doi.org/10.1007/BF00201550.

28. Banerjee D, Wong EC, Shin J, Fortmann SP, Palaniappan L. Racial and ethnic variation in lipoprotein (a) levels among Asian Indian and Chinese patients. J Lipids. 2011;2011:291954.

29. Lim TS, Yun JS, Cha SA, Song KH, Yoo KD, Ahn YB, et al. Elevated lipoprotein(a) levels predict cardiovascular disease in type 2 diabetes mellitus: a 10-year prospective cohort study. Korean J Internal Med. 2016; 31(6):1110-9. https://doi.org/10.3904/kjim.2016.030.

30. Hermans MP, Ahn SA, Rousseau MF. Lipoprotein(a) levels are doubled in left-handed patients with diabetes. Diabetes Metab. 2020;46(2):169-72 https://doi.org/10.1016/j.diabet.2018.03.005.

31. Rhee EJ, Cho JH, Lee DY, Kwon H, Park SE, Park CY, et al. Insulin resistance contributes more to the increased risk for diabetes development in subjects with low lipoprotein(a) level than insulin secretion. PLoS One. 2017;12(5): e0177500. https://doi.org/10.1371/journal.pone.0177500.

32. Kaya A, Onat A, Yüksel H, Can G, Yüksel M, Ademoğlu E. Lipoprotein(a)activated immunity, insulin resistance and new-onset diabetes. Postgrad Med. 2017;129(6):611-8. https://doi.org/10.1080/00325481.2017.1342508.

33. Rainwater DL, Haffner SM. Insulin and 2-hour glucose levels are inversely related to $\mathrm{Lp}(\mathrm{a})$ concentrations controlled for LPA genotype. Arterioscler Thromb Vasc Biol. 1998;18(8):1335-41. https://doi.org/10.1161/01.ATV.18.8.1335.

34. Reiner Ž. Can Lp(a) lowering against background statin therapy really reduce cardiovascular risk? Curr Atheroscler Rep. 2019;21(4):14. https://doi. org/10.1007/s11883-019-0773-y.

35. Sahebkar A, Reiner Ž, Simental-Mendía LE, Ferretti G, Cicero AF. Effect of extended-release niacin on plasma lipoprotein(a) levels: a systematic review and meta-analysis of randomized placebo-controlled trials. Metab Clin Exp. 2016;65(11):1664-78. https://doi.org/10.1016/j.metabol.2016.08.007.

36. Ferretti G, Bacchetti T, Simental-Mendía LE, Reiner Ž, Banach M, Sahebkar A Raloxifene lowers plasma lipoprotein(a) concentrations: a systematic review and meta-analysis of randomized placebo-controlled trials. Cardiovasc Drugs Ther. 2017;31(2):197-208. https://doi.org/10.1007/s10557-017-6721-6.

37. Sahebkar A, Katsiki N, Ward N, Reiner Ž. Flaxseed supplementation reduces plasma lipoprotein(a) levels: a meta-analysis. Altern Ther Health Med. 2021;27(3):50-3.

38. Enkhmaa B, Berglund L. Statins and Lp(a): the plot thickens. Atherosclerosis. 2019;289:173-5. https://doi.org/10.1016/j.atherosclerosis.2019.07.021.

\section{Publisher's Note}

Springer Nature remains neutral with regard to jurisdictional claims in published maps and institutional affiliations.

\section{Ready to submit your research? Choose BMC and benefit from:}

- fast, convenient online submission

- thorough peer review by experienced researchers in your field

- rapid publication on acceptance

- support for research data, including large and complex data types

- gold Open Access which fosters wider collaboration and increased citations

- maximum visibility for your research: over $100 \mathrm{M}$ website views per year

At BMC, research is always in progress.

Learn more biomedcentral.com/submissions 